Исидора Д. Ђоловић*

Универзитет у Београду

Филолошки факултет
821.163.41.09-31 Давичо О. https://doi.org/10.18485/analiff.2019.31.1.5

Originalni naučni rad

Primljen: 12.02.2019

Prihvaćen: 19.05.2019

\title{
ИСПЕВАТИ ПЕСМУ, ОСВОЈИТИ СЛОБОДУ, (РАЗ)ОТКРИТИ СЕБЕ: ФЕНОМЕНОЛОШКА АНАЛИЗА РОМАНА ПЕСМА ОСКАРА ДАВИЧА
}

Разматрано дело прати неколико упоредних струја свести, унутрашњих оглашавања која представљају драматичне душевне борбе јунака. Његова је најдубља тема онај велики напор да се пронађе смисао JА у збивањима и живота према ЈА-ству. Сва дешавања су преломљена кроз призму сумње, подељености и потреса који се у јунацима одигравају. Они испрва представљају две крајности, два драстична начела која се морају сусрести на средини пута и изнова открити смисао кроз компромис.

Кључне речи: феноменологија, подсвесно, рефлектовање, телесност, унутрашњи монолог, паралелизам

“...jер свака права песма наслућује сазнање, носи у себи сазнање, упућује у сазнање.“" (Херман Брох, Веріилијева смрй)

Мада је радња Давичовог романа лоцирана усред окупираног Београда, током свега два-три дана 1942. године, њено приповедно време је сложено, развучено и флексибилно. На исти начин се збивања, упркос не мање бурним и узбудљивим припремама за илегалну акцију пробоја градског обруча до слободне територије, вешто поунутарњују, те се њихов највећи и најинтензивнији део одвија у самим јунацима. Спољашња драма се још већом силином одражава на њиховим душама, чиме одговара још једном важном рефлектовању - ликова једног у другоме, односно, међусобној кореспонденцији која је напета и замршена. Тиме се површински слој радње, зналачки упреден у један ,подземни“, а пресудни, показује као тек пратећи, иако

*_isidoradj@yahoo.co.uk 
Исидора Д. Ђоловић

узрочно-последично усклађен. Песму сачињавају душевна и интелектуална треперења, постепено нарасла до правих тектонских потреса, низ осцилација на чијем се крају помаља вечито тражена светлост истине путем раскринкавања идеала, овде симболички богатог и већ насловом наглашеног. На свој начин, оба главна јунака сматрају да су извојевали за себе издвојеност, недодирљивост од околине, извесну супериорност - међутим, када свет око њих буде почео да се урушава, неминовно долази до преиспитивања унутрашњости бића и откривања некохерентности, напуклине што се брзо шири и наговештава застрашујућу празнину, коју може испунити једино вишезначна и моћна песма.

Кретање на путу њеног открића, дефинисања и остварења води од личног до општег, од егоцентричне усредсређености на себе до уграђености у колективно „здање“ будућности, до жртвовања за душу народа, али и утемељења онога личног. Средовечни песник Андрија Вековић и његов млади сусед, комуниста Мића Рановић, упадљиво су контрастиране, али у основи веома сличне могућности, које се крећу према истој тачки, истоветном искуственом и сазнајном исходишту. Због тога се, шире посматрано, ова два књижевна јунака један према другоме односе попут два супротна лика, одраза у огледалу. Кроз међусобно ривалство и тајанствену, несхватљиву повезаност, они стреме ка идентичном циљу, а спаја их (наизглед супротстављајући) привлачна удовица Ана Ђорђевић, заједнички љубавни интерес. Мића и Вековић један другоме прослеђују неопходне истине, допуњујући се: оно што је један већ проживео и схватио, другога тек очекује и неопходно му је као конститутивни чинилац личности. Вековић у Мићи буди потиснуте виталистичке снаге (оно субверзивно, изнутра-разарајуће, негирано) - животност, љубав према жени, успаване људске пориве; док Мића подсећа песника на сопствену младост и учи га чистоти идеала, доследности, повратку људскости у најчистијем виду, несебичности. Заједнички циљ је освајање песме (=слободе), тачније, поунутарњивањем доћи до испољавања, прочишћењем бића до суштине, до себе - и песме у себи као слободе за сопство.

\section{1. Гласови у нама}

Окретање себи, понирање у бездан забрањиваних и суспрезаних импулса личности која је веровала да ништа не може наудити њеној 
ИСПЕВАТИ ПЕСМУ, ОСВОЈИТИ СЛОБОДУ, (РАЗ)ОТКРИТИ СЕБЕ ...

самоизграђеној самосвести, води до откривања раздора и умножавања унутрашњих гласова као показатеља нарушене целовитости. Као што сваки комад стакла распршеног огледала има свој одсјај, душа је ишчезавањем одређеног ослонца изгубила сазвучје и постала збуњујуће, дисхармонично поприште сукоба. Монолошко пресабирање се отуда преобразило у унутрашњи дијалог, а мноштво сукобљених израза довело у питање сигурност личности у онај један, врхунски постулат на коме се до тада заснивала.

На почетку затичемо признатог и афирмисаног песника Вековића у тренутку животне клонулости, суочавања са старошћу и пролазношћу. Бури претходе празнина (остала иза дотадашњег пуног живота) и тишина - највећи пораз за човека који професионално барата речима: „Ништа. Ни мисли, ни осећања, ни покрета, ни сећања, ни праве туге. Једно ништа. Једно старо осећање да си непотребна, бачена, стара, тужна, глува ствар на коју полако капљу сумрак и тишина.“ Вековић осећа да се изненада у њему извршила темељна промена, а да је није наслутио, ни осетио.

Почетак сумњи у, до тада готово неисцрпне снаге, означава измицање вољене (и много млађе) жене. Истовремено, пољуљана је и песникова вера у смисао уметничке делатности, а један од главних узрока несигурности постаје управо млади комуниста Мића, донедавно извор потпуно супротног утицаја, будући да му је посредно вратио веру у живот и борбу („Феноменолог трага за тиме како се нека ствар првобитно приказала нашој свести, што је предуслов за схватање суштине у њој“ - Константиновић, 1969: 73, истакла И.Ђ.). Зато се он, наспрам Миће који је „блед, спокојан, али сочан од младости, од револуције“'(Давичо, 1982:12), осећа као мрйва, излаиела, акаgемска мешина: „Ти си једна тужна, одбачена, глува крпа која никоме не треба више.“(Давичо, 1982:10)

Силе се укрштају и сукобљавају (у тачки Ероса, па макар то у почетку било потпуно несвесно), а истовремено прожимају и утичу једна на другу. Захваљујући томе, кретаће се - и поред сукоба - један ка другоме, а кроз компромис успоставиће се потпуне личности у обојици. Међутим, пре тога је неопходно да се индивидуа унутар себе подели, располути, не би ли кроз двогласје - често и вишегласје (нпр. код Миће) - започело помирење са светом. Гласови у јунацима истовремено представљају савест и јавност, своје „ЈА“ и другога (друге). 
Они подвргавају провери, преиспитују, усмеравају ка самоспознаји и апсолутној искрености. Паралелни су са мноштвом Мићиних маски, његовим обичајем да улази у мисли пролазника и (за)узимањем одређених поза, израза лица, интонација говора, постаје неухватљив и недокучив: „Лице је ионако лишавао сваког одређеног израза, па га ни сад није морао да коригира, сем што га је, отворивши мало уста, учинио мекшим, безазленијим, чак и глупим (идеал је имати лице које и на улици и свуд где треба делује убедљиво глупо).“ Идеал је бити све и не бити ништа, јер недостатак дефинисаности онемогућава лак пораз. Млади револуционар то зна и увелико примењује:

„Но постало је код њега навика да улази у људе које би сусретао у пролазу. Макар да испита је ли то агент. Често, кад га пролазник не би забринуо, забављао се током дугих, усамљеничких кретања с краја на крај града тиме што је измишљао шта који од њих мисли.“ (Давичо, 1982:334)

Укидајући све што би могло да обавеже, ослаби, успори на путу борбе за идеал будућности, револуционар је слободан и ефикасан. Једина вредност, коју носи у себи, постаје му управо приврженост циљу. Нешто слично проналазимо и код Вековића, у исказу: „Да, али бити други, измишљати себе, бити своја чежња, бити слободан, то је стварати, то је борити се против свега неправедног и криминалног у случају живота.“(1982:55)

Мићине маске и начини обликовања сопствене појаве према потреби показују да је бораи одређење личности, али, не и карактер. Због тога се поставља питање „шта је то?“ и закључује: нешто „простије“, али, неухватљиво, недефинисано, још увек непознато. Мића се пита:

„Какав је његов карактер? Чудно. Не зна.“; „На улици је неупадљив. Неупадљивост се глуми. Он је вежбао да би добио тај ход и тај израз.“; „А сам, у својој соби? Револуционар није никад сам, ни кад је у својој закључаној соби. Он ни пре собом није неконтролисан. Постоји свест у којој је човечанство. Постоји огледало које те види. (...)Питајући се све то, Мића се смешкао себи с неком веселом горчином. Откад зна за себе, он је незадовољан нечим око себе, али и собом у жаришту тог нечег. Желео је увек да буде друкчији него што јесте.“(1982:326, истакла И.Ђ.) 
ИСПЕВАТИ ПЕСМУ, ОСВОЈИТИ СЛОБОДУ, (РАЗ)ОТКРИТИ СЕБЕ ...

Мотив огледала постаје нарочито битан за разматрање и разумевање Мићиног односа према другим људима. За сада је важно уочити на који начин се иза привидне флексибилности крије суштинска уздрманост, неутемељеност личности. Криза наступа када све оно што се чинило непомеривим ослонцем почне да показује своју противречност. Прва поглавља романа изводе пред читаоце Вековића, посусталог, пресахлог уметника и љубавника, а насупрот њега Мићу, строгог војника револуције. Па, ипак, ни један не уме да пружи једноставан одговор на питање идентитета.

Појмом консиирайивне мимикрије, Мића оправдава и уздиже дисциплинованост изнад свега, према њој се влада и њој све подређује. Сурови аскетизам својеврсне филозофије лишавања утиче на то како борац разуме и вреднује време. Садашњост је за њега простор стварања будућности, која у уобичајеном смислу за самог борца не постоји, али, гради је за друге, дејствовањем у своме добу. Мићин аутоматизам у понашању, реакцијама, чак и мислима - та апсолутна „истренираност“ - све је подешено тако да подржи његов имиџ револуционара, тим пре што никада юеїова најразличииија самойосмайрања нису имала естиейске ииљеве. У потпуности се прилагођава широј визији себе, тј. онога што би требало да буде, што МОРА бити зарад револуције. Веома велики, али негиран, јесте и удео сујете, коју нарочито испољава у односу према Петру и Ђорђу, саборцима и пријатељима.

Као и Мића, Вековић се издвојио у уметничку „кулу од слоноваче“, с том разликом што је отворио врата непрегледном низу жена: „Чекајући да напише песму незнане још силовите нужности и сретне жену неслућених чари (а шта су то неслућене чари?), он је писао песму за песмом и волео немилице жену за женом.“(1982:127) Вековића претерано не занимају човечанство, ни општи циљеви, све до познанства са Јеврејком Рејом и упливом гласова који наговештавају рат, али му и пркосе. Са учесталошћу насилних смрти и искуством губитка, Вековић се постепено отвара према савремености и ангажованости. Осетивши бол и доспевши у личну животну угроженост, он је потпуно спреман да помири уметничко бивствовање са пу(ч)ком егзистенцијом у немирним временима. „Бити сам“ сада представља увреду. На сличан начин, тек поставши „интерни побуњеник“ и под претњом одбацивања од стране колектива (Партије), Мића почиње да заиста, 
емпатијски, посматра људе око себе (првенствено Петра, Ђорђа, оца и комшилук), не више као нужну публику или мизансцен за своју херојску игру („Сажаљива љубав коју је Мића осећао јутрос и за те малограђане нагна га да се у мислима врати малопређашњем романтичном маштању, и да га коригира““, 1982:205), већ живе актере чија су осећања, ставови и мисли такође важни. Мића ће морати да буде до краја искрен према себи, призна и прихвати егоцентричне побуде, противречности (које настају када покушава да се одбрани по сваку цену), предрасуде и заблуде. Једино тако може истински постати нови човек, можда не сасвим у складу са захтевима својих „Свесних припрема“", али, зато по мери правог живота. Чак ни тада, због есенције његове личности, која у себи носи нешто искрено, другачије, занесењачко и неприлагодљиво, неће моћи да опстане. Али, барем ће достићи помиреност и извршити утицај на Вековића.

Пут ка самооткривању почиње јављањем унутрашњег раздора и ослушкивањем гласова који одјекују из насталог пораза. Вековићев двоструки неуспех чине Анин одлазак и Мићина освета, кроз претњу да му неће омогућити придруживање комунистима. Оба дебакла су повезана и проузроковао их је, боље рећи, испровоцирао сам Вековић, иако не сасвим свесно, ни намерно. Чињеница да га Ана напушта, за Вековића представља не само емотивни, већ још више крах мушкости, хедонизма као руководећег начела. Афера са праљом, која ће уследити, представља очајнички потез и покушај да себе убеди како кризе нема. А расцеп личности означавају управо сукобљени гласови који преиспитују:

„Излапелом песнику ни слободна територија не помаже.

Ти то знаш. И шта се онда завараваш толико времена? Зашто обмањујеш себе и не само себе? “(1982:10)

Унутрашњи дијалог, двогласје у јунацима, метода је тражења истине о себи - у себи. Вековићева дилема концентрише се око побуда за укључивање у револуционарну акцију, проблематизујући његов однос према слободи: „И ти је волиш? Теби није пуних 56 година пуцао прслук за њоме, није? Је ли, себичњаче? Стало ти је до слободе? Реци.“" Први пут се, управо посредством пробуђене унутрашње „пороте“, поставља захтев за потпуном искреношћу: „Погледај ме, чикице! Погледајмо се како то само ми знамо. До дна. Тамо је и 
ИСПЕВАТИ ПЕСМУ, ОСВОЈИТИ СЛОБОДУ, (РАЗ)ОТКРИТИ СЕБЕ ...

одгођено поштење исто што и непоштење.“ (1982:11) Вековић ће се вратити у прошлост и преиспитивати развојне промене свог егзистенцијалистичког становишта.

За то време, Мића уочава сукоб идеологије и стварности, суровост личних високих захтева и мерила. Он жели да буде човечан кроз челичну дисциплину и строгоћу („Били бисмо бедни лажови, не творци слободе, која је истина. Зато треба гледати лењински на ствар и запитати се шта би Лењин урадио у тој ситуацији.“, 1982: 27), да покаже љубав према човечанству укидањем сопствених слабости (,„Ј нисам према судбини света равнодушан. Јер ако ме се не тиче лични живот другова с којима се борим, не тиче ме се ни мој. Ja ћу се пропити, прокурвати, а рад, а борба?““, 1982: 37), ширину кроз одрицање, будућност преко одбачене садашњости. Његова спољашња борба је она против окупатора, а унутрашњу воде свест и воља против сна и жеље. Како примећује Ђорђе, Мића има „некакву чистунску представу о животу, и зато што живот не одговара тој представи о њему, хоће да с прљавом водом из каде проспе и живот у канал.“(1982: 37) Хтења, уколико и постоје, само су она која сами себи дозволимо: „Непријатније је носити главу у торби, палити камионе, бежати и пуцати у издајнике но ићи у биоскоп, позориште, читати књиге пуне козметизираног живота спремног да корзира. Али лафови и лафице не дижу револуцију. Ни у тим романима.“ (1982: 38) Он искрено признаје да лейше оg йарйијскоі раgа не може ни gа замисли, а како је морал „оно што нас држи кад га се држимо“, утолико је строжи према себи уколико погреши. Вечити опрез, будност и селективност памћења, Мићине су водеће мере предострожности, јер „борац не сме да разочара“, а „сумњање је данас у служби непријатеља“. Други глас у свести ово доводи у питање.

Мића од малена испољава страствену природу на граници са фанатичношћу, потпуну и дубоку приврженост свему: од различитих видова борбе за „укидање бола човечанства“ (најпре кроз ђачке дружине и „мисије“), преко схватања љубави (чисте, идеалистичке наклоности), па до делатности у оквиру Партије, подухвата којима приступа свим срцем и енергијом. Али, већ ту се јасно појављује проблем телесног као непријатељског, скрнављења идеално замишљене љубави у мотиву спаривања уличних паса и Мићине агресивне, пренаглашене мржње, огорчености и испровоцираности: „Можда би 
тад и он у овом часу померио и изударао штапом Вековића као пса, као давно оне слепљене псе, као онда кад је као дете сломио псећу кичму оним слепљеним псима који су то чинили под прозором Јелкине куће...“(1982:110) Ова анимално-гротескна сцена поновиће се и када буде случајно присуствовао Вековићевом завођењу вешерке на тавану, а које ће послужити као окидач сукоба и наизглед главни узрок противљења песниковој даљој сарадњи са Партијом.

Мића се, из тренутне перспективе, нерадо сећа и своје једине дечачке љубави - сусетке Јелке, блеgе, ломне и йлаве, gруіачије og

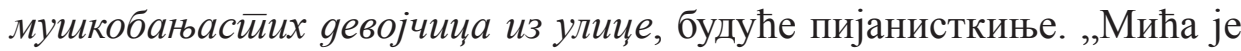
тада маштао да је маскиран, на коњу, наоружан до зуба, отима и одлази с њом далеко, где никог нема, негде у шуму, велику и опасну шуму, где је већ раније у мислима крај дубоког језера подигао кућу за њу и себе.“(1982:194) Док је била болесна од шарлаха, шест недеља је под њеним прозорима йо сне̄̄y и кошави, чекао gа озgрави. Заплакао је кад се коначно појавила, слаба, али, ван опасности и „тог тромесечја је донео четири двојке. Једине које је имао за осам година гимназије.“ Каснији случајан сусрет са Јелком одиграће се на улици - она је сада сарадница окупатора, бујна йлавуша с їруgима ийо су је као йоgі̄уркивале у хоgу ірабећи найреg, некако увек исйреg ње, а Мића се, оптерећен тешким мислима, опрашта са својим градом. Истакнут je, у читавом портрету девојке, управо мотив женских груди, Мићине подсвесне опсесије. Он заузима очекивано одбрамбени став, реагује хватајући револвер у џепу, а за Анино писмо које такође напипава као још једну претњу, помишља да је требало да га баци у канализацију. Мића осорно и бунтовно тврди самом себи како никада није био заљубљен.

Постоји, ипак, нешто што Мића неспутано и нескривено воли. Свој позив, разуме се - и то искрено: „Увек је волео посао који је радио. И није га само онако волео. Него се заљубљивао у тај посао, и заљубљујући се, све више фиксирао на њега све своје мисли и неосетно почињао да потцењује све друге врсте активности. (...) Била је то ствар срца, његове природе склоне уопштавању.“(1982:196) Посао је, природно, барем у почетку поистовећен са колективом. Приликом првог изразитијег сукоба, управо у судару партијског и личног става (по питању Вековићевог компромитовања), јавља се изразитија сумња: „Стресе се. Откуд му претензија да буде увек паметнији и зна 
ИСПЕВАТИ ПЕСМУ, ОСВОЈИТИ СЛОБОДУ, (РАЗ)ОТКРИТИ СЕБЕ ...

више од свих. Језа није престајала да му се слива низ леђа и он осети поново, као по подне, онај скоро мистични страх светогрђа. Устао је против одлуке, линије. Против свега, значи. И против самог себе. Био је луд.“ (1982:430, подвукла И.Ђ.) Уверавајући самог себе да „Партија не греши никад“, Мића потврђује оно што је недавно прекоревајући говорио Петру:,Ти и не знаш шта је Партија. Слобода је она. А не тиранија, не присиљавање, не терор. Слобода.“ Међутим, унуташњи дијалог пружа нове погледе:,Како не греши никад? А шта су познати самокритички осврти на протекли период рада? Партија не греши никад. Бар не у тренутку кад је заузела став да би га остварила. Самокритика може доћи после.“(1982:430) Због тога ће у кључном тренутку Мића схватити да је његов его био сувише снажан, а хуманистичке побуде апстрактне и дистанциране од реалности:

, Али тај живот, до ког ти није сувише стало, није прави живот, јер није радостан, као што ни твој смех није љубак, ни весео, него намештен. Зашто? Не можеш се жртвовати кад никог не волиш.“; „Гласови су за то време престали да се чују и Мића осети бол од те тишине у срцу.“(1982:457, истакла И.Ђ.)

Ово отрежњујуће сазнање показаће Мићи колико му је заиста стало до других, а колико је избегавао да се са њима у правом смислу повеже. Гласови су, заправо, били неопходно подсећање на то да извођење сваке револуције започиње у самом бићу, да његов однос према људима мора бити непосредан, искрен, истинит. Они коригују сваки Мићин трапави покушај да се оправда и избегне суочавање са аутоматизованом, а готово дехуманизованом личношћу коју је начинио од себе. Симболи огледала и воде, повезани углавном са Аном, наговештавају преокрет који ће уследити.

\section{2. У огледалу и магновењу}

Мотив одраза се често појављује, било у виду огледала или воде, било кроз симболично суочавање двојице актера преко паралелизама, упоређивања, сучељавања становишта. Огледало поседује, баш као и претходно поменути гласови, сазнајну функцију - (раз)открива, суочава и рефлектује оно најскривеније, а исконско у јунацима. У огледалу Мића види себе, Ану, Жику; метафорички, Мића и Вековић су 
као супротни одрази; кроз огледало се успоставља право саосећање, уживљавање, додир са човечанством.

Мића ће Ану први пут угледати на слици, она њега у огледалу, a „конце“ ће (посебно испрва) повлачити Вековић, Мићин истински обрнути одраз. Оно по чему Мића не жели да буде сличан Вековићу, чулност и сладостраснички пориви, заправо их спаја на подсвесном, најдубљем нивоу. Остаје отворена могућност да је Вековић младићев биолошки отац, због давне афере са његовом покојном мајком (заправо, напаствовања). Док песник на то уопште и не помишља, за Жику Рановића је питање очинства највећа „рак-рана“ и разједајућа сумња готово подједнако обележава његов живот као и несагледива, опсесивна љубав према Деси и сину, кроз кога она као да још увек живи. Што се Миће тиче, као четворогодишњак је начуо жестоку очеву расправу са пријатељем Дачом, али, готово сигурно није разумео, нити запамтио било шта од изговореног. Међутим, од тог тренутка дете полагано мења однос према оцу, затвара се у себе (што је пре одговор на Жикине све веће и оптерећујуће изливе родитељске љубави-стрепње, него показатељ било какве личне сумње), али „подземни ток“ ће на видело избити тек касније, кроз Мићино необјашњиво, а интензивно гнушање над свиме што је чулно, телесно, што нарушава чистоту идеала. Као да душом и оним њеним надразумским делом слути прљаву епизоду која се давно одиграла између његове мајке и песника, Мића ће бити потресен и необјашњиво гневан због сцене између Вековића и вешерке (готово поновљена историја!), а нешто касније и немачког војника са проститутком (зато оно неправилно изговорено сфесие постаје рефрен блуда, ишчашености, нечег недопустивог):

„Осећао је неку муклу непријатност, гађење, скоро, безразложан страх, а лист леве ноге му се тресао у лаким грчевима сличним цвокоту.“(1982:100, истакла И.Ђ.)

Његово интуитивно знање (подсетимо се Ингарденовог учења о интуицији као апсолутном сазнању) опире се преласку у рационализовано САзнање, јер би истина била поражавајућа по савршено дисциплинованог револуционара, „емотивног робота“. А она гласи: не само да је Мића можда плод једног тако прљавог чина, већ и сам у себи носи суспрегнуту жељу да буде сличан Вековићу и осталима који јој се без размишљања предају: „Нема победе свести. Нема воље! 
ИСПЕВАТИ ПЕСМУ, ОСВОЈИТИ СЛОБОДУ, (РАЗ)ОТКРИТИ СЕБЕ ...

Мислио је Мића, али пре но што се следи од ужаса, стигло је да му се учини да он то место Вековића носи, исто, на рукама, ону девојку у белом, Вековићеву поћерку и, не зна шта му је, зар је он тако...“-„НН. То би била издаја, а ја то никад нећу.“(1982:109) Због тога бурно реагује, на подсвесном нивоу испровоциран, искушаван.

Мићино схватање љубави као у корену извитоперене, покварене, самим тим и неопходности њеног „поновног измишљања, стварања“, долази до изражаја управо у размишљању које га заокупља након Вековићеве авантуре: „Себична је и одвратна та љубавна игра у својој тежњи ка апсолутној лакој пријатности, том тренутку изван времена и простора. Она тражи два цела човека за дезертирање с попришта.“; (1982:113) Љубав сведена на телесно, у овом тренутку је двоструко погубна, нека друга врста йесме (асоцијативни ток помињањем заводљивости упућује на сирене) - празне, дивље и примитивне (поређење са племенским ритмовима, у натуралистичкој слици „трзаја у ритму слузи, у грчевитом тамтаму измућканог ликвора мождине“).

Оно што Мићу посебно угрожава и посрамљује јесте чињеница да је, упркос покушају оправдања како га је „интерес за ствар задржао, будност, не радозналост, не радозналост на првом месту“, био на бизаран начин привучен воајерском чину. Још горе, ЖЕЛЕО ЈЕ да буде на Вековићевом месту. Отуда долази и одлука да друговима не каже gа је вияео шйа је вияео, из сиираха gа они не иомисле за

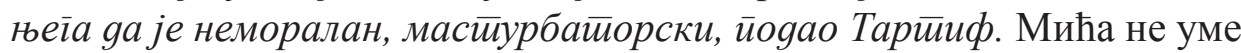
да увиди разлику и за њега постоје једино крајности, једино строго раздвајање на војнике и gезериеере ияеала. Додатне показатеље да су такви пориви у њему заточени, али не и убијени, представља најпре однос према Аниној слици и женама уопште: „Но упркос тој мајсторској мимикрији, њега је, у тој прилици, издавало фиксирање“ (Аниног портрета, прим. И.Ђ). Вековић индиректно подстиче, код обоје, „несвесну љубав која је почињала“. Приликом последње посете Вековићевом стану, Мића скреће поглед ка удубљењу међу полицама са књигама и примећује да нема Аниног портрета, али, не придаје значај том запажању, нити се икада распитује о моделу. Затим, веома су важни његови снови и подсвест, као и реторика (говор и мисли) поводом питања љубави и веза, а која је подругљива, разуздана и омаловажавајућа, међутим, назире се њено опседајуће и мучитељско дејство на Мићу. На пример, овако друговима говори о Вековићу, ар- 
Исидора Д. Ђоловић

гументујући своје мишљење да песник није достојан да им се придружи:

„Но док ће борци гинути на положају, он ће им заводити сестре, девојке, жене. Људи гину, а он се ваља по стрњици с њиховим драганама, притишће их уз плот, обара у јендек, мази у штали, руши у обору....Пљујем на такав магнет.“(1982:41)

Мићин гнев освете побуђен Вековићевим чином, $\bar{u} а$ необјашњи-

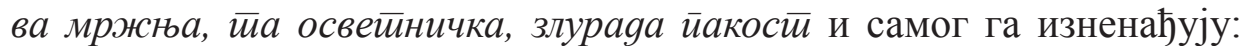
„Откуд то? Зашто? Шта ће то једном борцу? Његови поступци досад су црпли подстреке из сфера племенитих осећања човека. Па откуд онда? Није знао. И није могао знати. Али се није желео отети зрачењу те осветничке пакости.“(1982:141) Позивањем на своју етичку мисију, Мића изводи песника пред суд личне, специфично схваћене правде, коју је приметио још његов отац, човек који га вероватно најбоље познаје и први реагује на синовљев морални радикализам:„Нешто немогуће је расло пред Жикиним очима: син који хоће немогуће и који поступно налази смисао у порицању. Све му је постало јасније, Мића је рођени негатор, стална опасност за све што постоји, чак и за бол и љубав - једино што је Жика разумео.“ (истакла И.Ђ.)

Мићина приврженост мисији „укидања бола“ почиње веома рано. Одрастајући без мајчинске фигуре (Деса је умрла на порођају и никада је није упознао), од раног детињства оснива различите тајне дружине, које су му много значиле и у којима, по правилу, води главну реч. Жика је „осећао да ће после тих неплодних завера за исправљање појединих окука криве Дрине живота, ускоро севнути муња у чијем ће блеску Мића сагледати ту Дрину у целини и тек онда пожелети да је сву измени. Цео живот. Из темеља.“ Наслућивано се догодило пошто му је убијен ујак, комуниста, откада се Мића повлачи у себе, не напушта собу, нити се јавља друговима. Уместо свега тога, почиње да пише дневник назван Свесна ирийрема, који постаје манифест његове будуће акције: „Мића је седео над књигама у закључаној соби (почео је да се закључава) и радио, радио до касно у ноћ. Као да је жудео да сазна што брже и више од свега што се могло сазнати. Просто једна неутољива глад. Читао је књиге Слободана Јовановића, Мишлеа (о француској револуцији), српског црвендаћа и бунџију Светозара Марковића, Џона Рида, Бухарина.“(1982:253) Јасно је и против чега 
ИСПЕВАТИ ПЕСМУ, ОСВОЈИТИ СЛОБОДУ, (РАЗ)ОТКРИТИ СЕБЕ ...

се (најпре у себи) најватреније буни: малоірађанин је за Мићу свако ко тежи да му буде лаїоgно.

Посматрајући из прикрајка синовљеве постепене и све заоштреније промене, Жика се пита: „Зашто то Мића хоће да избаџи из себе као мрииваца и последњи себични рефлекс? Зашто му треба воља тако мишићава и снажна? Шта хоће да постигне дневном гимнастиком воље? Да постане неосетљив на бол и на слабости? Чему?““(1982:254) Парадоксално, његов изглед као да се опире стегама: „Мића је одиста радио све могуће да огруби, посурови, али лице му је остајало љупко упркос мршавости и извесној повременој спољној расејаности која је ишла укорак с утиском да је вазда занет мислима и да непрекидно напето и врло концентрисано машта.“ Другови су посебно уважавали Мићину стирасну и, у истио време, као у арииистие иррорачунатиу ирироgу, храбрости луцияну више неіоли сйонйану, знање и ненайлашавану моралну чврстиину - скромности која их је заgивљавала. Поређење са артистом није безазлено: „Оно што је музичару конзерваториј, вајару академија, Мићи су представљале године свесне ирииреме. За то је време Мића потпуно загосподарио свешћу и вољом, то јест, својим телом, сведеним на послушан инструмент. Не егзистирајући својим самосталним, независним људским животом, тај инструмент у служби револуције није изгубио ништа од људског чара младости.“(1982:264)

И баш због силних упињања да негира своју чулност, једно једино искуство са сусетком, вулгарно атрактивном женом коњичког

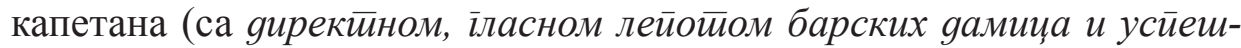
них йросииийуйки, 1982:255), показаће драстично дејство кривице и изазвати искрено гнушање, кајање, самопрекор, те жељу да се путем казне искупи, али истовремено и очеличи против будућих слабости. Начин на који Вековић види Мићу открива наслућени немир који разједа младог револуционара, попут таласања испод залеђене површине језера. Мића га фасцинира, истовремено мотивише и разјарује, диви му се и мрзи га (доживљава као конкуренцију, мада сопственом кривицом), а пре свега подсећа на сопствену младост и давно одбачен,

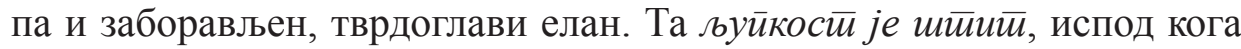
Вековић закључује да је Ана ойкрила gивљу, сиирасну, заиенушиану рушилачку бунииарску снайу која је йо нечему и юу морала йоgсейийи на Вековићеву, на моју gавну силовитооси, обуздану само вољом gа йишем иесме (1982:19) 
Нема сумње да песник почиње мерити себе, прошлог и садашњег, према младићу. Подсвесна опсесија Мићином личношћу, варира од замаскираности љубомором и супарничким односом, до угледања и поистовећивања. Прва замена идентитета, по чулности, настаје када се Вековић праљи представио као Мића. Друга истоветност, по храбрости, почиње од говора на гробљу и врхунац достиже у заробљеништву: „, И ја ћу бити херој, мученик, нећу одати, иако ми је 56 година. Сад се осећао исто са херојима од двадесет година. Сагледао је он те младиће до краја. Знао је шта су, ко су. Он је сада исто што и Мића. Увек.“(1982:445, истакла И.Ђ.) Вековић тежи да подражава, следи истрајност и издржљивост младих комуниста. Посебно је упечатљива игра речима у којој се, у једном тренутку, престају разликовати личности песника и Миће, ЈА и други: „, Издам ли га - ухапсио сам себе још једанпут. Не издам ли га, ја ћу се борити с њим. Да никог не муче. Не издај га.“ - „Воз за возом. У исти мах. Воз за возом, не издај се, пролазио је, не издај га, безбројним колосецима, не издај се, предграђа његових мисли, не издај га.“ (истакла И.Ђ, 1982:462) Издати другога, постаје једнако издаји самог себе, посебно уколико је тај други помогао да досегне оплемењеност. А Вековићеву стваралачку блокаду (јер, једино у песништву он истински постоји) победили су управо осећања према Ани, откривање радио-сигнала немачке „Станице слободе“ и познанство са Мићом, дакле, љубав и револуција.

Ана се присећа ових Вековићевих речи и првог виђења Миће $y$ oйлеgaлy, где јој се на тренутак указао „танак, нељудски витких пропорција“. За Вековића, борба је йајна вечиие млаgосиии, сииално йомлађивање. Мића га испуњава несигурношћу, јер сада ОН „има права“" на оно што је Вековићу измакло. Због тога песник жели Мићину младост и енергичност, док младић (несвесно) жуди за његовом виталношћу и одважношћу да узима све од живота (отелотворено у Ани). Вековић у Мићи препознаје сопствену потиснуту, укроћену силовитост: „Од првог тренутка осетио сам у њему ону унутрашњу напетост која је и мене чинила оним што сам. Као губава магарад што се нањуше, намирисао сам и ја у њему - побуњеника.“(1982:65) Док Мића, коментаришући Ракине песме и критику, износи мишљење да његов друг „мора научити да подноси ударце“, Вековић у томе препознаје „гордост и протест, очајање и срећу, вољу и немир, самоубилач- 
ИСПЕВАТИ ПЕСМУ, ОСВОЈИТИ СЛОБОДУ, (РАЗ)ОТКРИТИ СЕБЕ ...

ки бол и мазохистичко уживање и, упркос миру са којим је то рекао и упркос осмеху којим је пропратио своје речи, било је у њима и њему толико заузданог очаја“, да му се учинио као „човек који је отров живота претворио у лек“(1982:65). Закључује како „Мића није био уметник. Био је стваралац живота.“ Касније ће га подсетити на икону

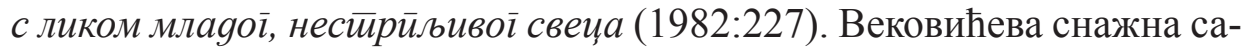
моконтрола почивала је у песништву, Мићина у револуционарности. Симболика се наслућује од тренутка када Вековић на месту Аниног писма за Мићу, одложеног на писаћем столу, угледа посмртницу генерала Урошевића (позив да одржи говор на погребу). Повезивање које се тиме успоставља, на симболичком плану, двоструко је. Наго-

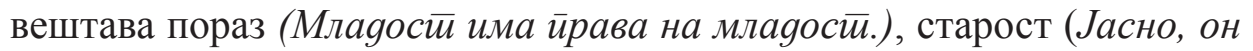
има времена, млаg је) и смрт, али и предају (љубави) и побуну (која се припрема кроз говор на гробљу).

Интересантан је контраст између Мићиног и Вековићевог односа према сновима (и подсвесном). Док их први потискује, боји се, види их као препреку и непријатељско у односу на свој свесни, вољни циљ, Вековић кроз њих тумачи сопствени свет, идеале, разочарања и наде. Радо их анализирајући, односи се према ониричком на јави путем супротстављања. Мића сфере несвесног доживљава као негацију сопства: „Он никад не сања. Скоро никад. А и тад - скоро ништа не би запамтио.“ Врлина нейлћеюа снова спада међу највеће предности једног борца: „Боље је овако, неоспорно. Рука с револвером му још није задрхтала кад би, атентаторски витак, искочио из заклона и почео да пуца, пажња му ниједном није одлутала ни с једног састанка.“(1982: 79) Међу елементима чулности који заокупљају Мићину подсвест доминира мотив женских груди. Оне су увек „живе“, нападно истакнуте, а у Анином случају се готово непрестано инсистира на њиховој ,лепршавости“, попут контраста Мићиној суспрегнутости, укочености дисциплине.

Као да тражи оправдање, а истовремено и признање, он истиче како је ,лепше и теже бити револуционар. (...) Ми се одричемо свог права на загрљаје и пољупце које сваки створ добија са животом. Али ја нећу погинути.“(1982:470) И наставља: „Они не знају за увреду окупације, за горчину неслободе и стрепњу и крв што се лије. Они су заборавили на то.“ C једне стране гневан због „непоштовања“ љубавника према борби, с друге их оправдава: шта друго могу да ура- 
де? Зар нису они, у свом затвореном рају, већ сад пронашли оно за шта се сам бори? Бојков план да побегне са комшиницом Десом у свет такође је својеврсна побуна против окупације. Унутрашњи сукоб између дела личности који се одупире љубави као „дезертерству“ и другог гласа у себи, који је суштински усамљен и жели да буде вољен, посебно је видљив у преиспитивању: „Али од свих смрти, можда би најлепша била у загрљају. Шикнути загрљен, умрети као у сну. Тако је уснуо војник да је умро лепше но на бојном пољу. Сфестие! Мића се прекоре. То је због месечине. Живот није сан! прекори се. Ни погибија. Ни сфесте. Живот је борба и будност, будност, будност у борби.“(1982:475, истакла И.Ђ.)

Вековићев упечатљиви и вишезначни сан заузима значајно место у роману. Први његов део садржи исказ: “Еj! Не бацајте ми књиге! То су моје песме. У њима је цео мој живот.“(1982:80), који потврђује да живот у песмама јесте живот у слободи и уметности. Јер: „Он је бранио корен свог револта, али тиме и постојање. Језик.“ Тај кошмар, у коме су све жене које је волео окупљене да слушају како чита своју поезију, при том све до једне - као и Вековић сам - прекланих вратова, потресно и незаборавно указује на крах вредности и идеала, те позива на побуну, на крик. Буђење доноси одлуку о ступању у борбу, а први корак ка новој освешћености биће јавно иступање на погребу.

\section{3. Сазнањем почиње борба}

Кулминациона тачка, гранична ситуација у коју књижевни јунак доспева, омогућава спознају без које се не може извршити преокрет у бићу, ни сагледати живот. То су оне „ситуације на прагу“, како их назива Бахтин, када појединац доспева у судбинске околности, а говор се чисти од аутоматизма (свега неважног) и открива најдубље слојеве личности (кроз самоанализу и саморазумевање). Углавном се ради о искуству додира са смрћу, егзистенцијалној угрожености - без обзира да ли је у питању опасност по себе или друге. Спознаја бола, у оба случаја (и код Миће и код Вековића) доводи до свести о човековој ништавности пред физичким и метафизичким детерминизмом и истовремене немогућности да се помири са тим, па врати у своју „безбрижну себичност". Откриће бола захтева покушаје његовог укидања, разликују се једино начини предузимања акције. Код Миће, реч је о детињастом, тврдоглавом ентузијазму који прераста у идеолошку опредељеност и 
ИСПЕВАТИ ПЕСМУ, ОСВОЈИТИ СЛОБОДУ, (РАЗ)ОТКРИТИ СЕБЕ ...

револуционарну акцију. За Вековића, то је покушај борбе сопственим средствима (речима, које су његов живот и срж уметниковог бића, стога се борба заправо води читавим постојањем), преокрет у природи песме као оружја, новооткривеној и сагледаној другим очима. Мића се тражењем „анти-бола“ декларише као борац за опште добро, а истовремено дистанцира (узноси) у односу на колектив. Његова одлучност и спремност на жртву, самоопредељеност за аскетизам ратника, уједно означавају специфичан понос, горду осамљеност, строгоћу према себи и осталим „носиоцима заставе“ (која је још један важан симбол), а снисходљивост у односу на народ за који се (декларативно) бори. Мићино обезличавање (на плану илегалних акција и тзв. „конспиративне мимикрије“) грубо се сукобљава са, изнутра веома јаким, егом и свешћу о изузетности подухвата. Због тога је неминовно његово очовечење након граничног искуства (потере и угрожености, не само живота, већ и задатка - чије је извршење корак ка Мићином животном циљу). Он ће бити принуђен да се суочи са грешкама које је на том путу правио. Иако суштински не одустаје, нити мења идеал и правац, мораће да промени начин његовог постизања. Он се први пут сасвим отворено суочава са собом, „до краја искрен“ и кроз сумњу пронашавши ново поверење у људе, нови однос према времену и акцији, очовечење насупрот дотадашње аутоматизованости.

Вековићево преобраћање одвија се у супротном смеру. За разлику од младића, песник ни једног тренутка не заварава себе да му је посебно стало до околине. Својим опредељењем за живот у стваралаштву, на неки начин елитну позицију, одавно се удаљио од преокупација свакодневнице. Тек кроз познанство са Рејом и почецима страдања Јевреја из њеног круга, а потом и окупацијом, у његов живот изнова улазе давно заборављене дилеме и питања, а појам слободе добија на вредности. Поезија постаје зрелији, потпунији и делотворнији вид суочавања са животом и неправилностима света. Стваралаштво је компензација за младалачке побуне без смисла и ефекта, али и својеврсна утопија, утеха, лек - ирейварање вина наgе у крв реалносии и (1982:120). У годинама непосредно пред рат, јасно је да и Вековићево песништво мора постати другачије. Након што је „испао на калдрму из ишчашеног бедра судбине и осетио нехуморан бол бола“, поставиће себи питања: „Куд се дела моја хуморна равнодушност? Шта је постало од моје радне себичности?“(1982:54) 
Исидора Д. Ђоловић

Ипак, пресудно је познанство са Мићом и његовим саборцима, у чијој храбрости и одлучности Вековић препознаје своју прохујалу младост. Приближавањем и стицањем њихове наклоности тежи да оствари акцију, те докаже себи и ближњима (пре свих Ани, не би ли је задржао) како је још увек способан за велике подвиге. Међутим, то није довољно, па ће све до тренутка хапшења и пребијања, код Вековића сваки поступак бити вођен егоистичном жељом за осветом, доказивањем, надигравањем (као и код Миће). Тек рањен и остављен у потпуно отвореном суочавању са истином, Вековић је кадар да искрено приступи борби, свестан шта она заправо представља. До тада су његове песме и жене (љубави) биле тек нешто више од средстава прибављања хедонистичких „горива“. Пред личном угроженошћу, ишчезавају „хуморна равнодушност“ и „радна себичност“, а Вековић - баш као и Мића - схвата истину. Изнад свега је задивљен херојством младих комуниста, издржљивошћу у оданости (решености да се не изда), спремношћу на жртву - што ће и сам пожелети да досегне. С друге стране, Вековићево искуство љубави мора бити проживљено код Миће, док песник открива искуство дисциплинованог живота, одрицања и сапатништва, борбе и акције. Слобода, за Вековића, постаје „стално човеково освајање. Никад освојиво, као ниједно сазнање. Али нужно да би се постојало. Према томе и оправдано. И вредно да буде мотив поезије.“(1982:144) Тежину и вредност јој пружају њено ограничавање или потпуно ускраћивање, а живот се почиње схватати и ценити тек када спознамо бол и опасност.

Кулминациона тачка за Мићу такође је непосредно суочавање са смрћу, тачније, скривање у контејнеру пред агентима који га гоне. Тада се његова личност „цепа“ на два дела. Ово неизбежно суочавање представља корак ка прочишћењу кроз друге - у осећању кривице због Петра, Ђорђа и оца. Кроз очај због кога коначно гази самозадате принципе и препушта се Ани, настаје „нови човек“, а у „радости борбе“" доћи ће и до смрти вилиноі коњица - баш како је замишљао: нагло, у акцији, изненада. Пре тога, у подељености на старог и новог себе, садашњост за Мићу добија другачије значење. Његова прорачунатост најпре прихвата чак и улогу „макроа револуције“, па одлазак код Ане оправдава тиме да ће учинити све што је потребно, служећи свом циљу, не би ли постигао ослобођење (себе) и оправдање (циља и себе). 
ИСПЕВАТИ ПЕСМУ, ОСВОЈИТИ СЛОБОДУ, (РАЗ)ОТКРИТИ СЕБЕ ...

Неизоставно је размотрити Мићин однос према истини. Поред слободе, она је за њега врховна, узвишена вредност. Бити неискрен према другима, а још више према себи, представља највећи грех. Али, подсвесно слутећи да се вара, он страхује и уједно бесно негодује против лажи (недоследности) коју је препознао у Вековићу. Мића се очајнички бори да потисне све што би га представило као рањивог, слабог, „људског“ - а не „новог човека“, машину револуције, оружје будућности. У Мићиној свести, садашњост нема значаја, а пошто у будућности вероватно (томе и тежи, жртвовати се за земаљски рај) неће постојати, његов је живот самонегација, свесно самоуништење за виши циљ и апстрактну, универзалну правду. Слобода је йесма, истина, правда - (вероватно) не за мене, јер мене неће бити, већ за друге, за све. Идеално би било уградити себе у споменик будућности, кроз апсолутно пожртвовање, довести до укидања „ЈА“ како би се постало - свет. Ово Вековић тек треба да схвати и усвоји, а његова идеја иесме је заправо универзално јединство са бићем свега, са постојањем.

У том смислу, веома је битна категорија садашњости и времена уопште. Она на крају, прочишћена, подразумева да је неопходно живети у садашњем тренутку, сагледати и прихватити ствари и људе онаквима какви јесу, бити искрен према себи. Живот у прошлости или будућности никада није сасвим искрен, ни истински, а при том носи и необјективан однос према другима. „Безвременост“ код Миће није негативна, напротив, али повлачи исувише строге критеријуме за људе и сопствени живот. Наспрам ње, Вековићева прошлост (у слави и снази младости) и будућност (ненаписана, безоблична песма, коју стално одлаже и слути) такође удаљују од реалности и конкретног делања. Бити у садашњости значи бити објективан, бити за друге - у правом смислу испунити улогу борца.

Мића зна да је садашњица време яизйина, самоgисцийлине, иррављења себе, рањавања себе, амйуииирања себе: „Бити извршилац налога историје није само њихов живот, него живот ове епохе. Према томе, мој живот јесте не бити све што бих могао бити да бих био само оно што треба данас бити. Бити војник, то је данас бити. И мој је карактер - војнички.” (1982:331, истакла И.Ђ.) Мићино схватање борца у времену је следеће: „Он треба да изврши свој историјски задатак, и нестане, то је налог целог живота у њему. Да се не пита, не мучи, не распиње. Да дејствује у одбрану чистоте заставе под којом се 
ваља парни ваљак револуције. То је битно.“(1982:333, подвукла И.Ђ.) Чак и када се не слаже са временом и када су му неприхватљиви његови владајући стандарди, он нема право да саботира општу добробит. „Схватити озбиљно садашњост значи бити спреман да се сваког часа лишиш свега ради њеног постојања. Свега: задовољства, живота. Али Вековић то не може. Не може ни на слободну територију.“(1982:334)

Мићино самопорицање, негирање свега, па и себе, има дубљу сврху - све мора бити уништено да би нестао бол (светски бол, бол човечанства као Мићина опсесија), а онда се мора изнова створити, „измислити“. Његово неспокојство је одвајкадашње и дубинско: „Пуно којечега није умео. Није, на пример, знао да се радује непомућено. Чим би се насмешио, помислио би: на земљи има људи који тугују. На земљи их увек има. То је код њега била болест. Гонила га је да тражи лека.“(1982:353) Однос према колективу и припадност Партији важно су одређење његове личности. Највећи пораз постаје одбаченост, неповерење другова, изопштеност из групе. Откинут, ускраћивањем могућности да погине за идеал, он је лишен смисла. Јавља се дилема: ко сам ја (сам), али и шта сам ја САМ (без другова), чему борац без сабораца? Ако не могу потврдити свој брижљиво грађени идентитет револуционара (Мића), ако не могу написати песму слободе, песму сопства стопљеног са светом (Вековић), онда смисла нема и ја немам излаза.

Управо услед такве привржености дисциплини, непрекидног лишавања и строгоће, ударац ће бити јачи и последицама драстичнији по Мићу. Тим више се поколебао, што је био сигурнији да не греши, строгом арбитрарношћу одбацивао туђи учинак као недовољан и поступке као недоследне. Оставши одбачен од другова, надгласан, осујећен у свом „гордом човекољубивом експерименту“ (није ли сама конструкција ове синтагме одраз Мићине унутрашње неусаглашености?), Мића ће најпре осетити кривицу. Грижа савести уноси разлику и посебно мучи, јер је следећи корак признање злоупотребе одговорности коју је имао за друге, а потом и преиспитивање себе као борца.

Страх од смрти, како на први поглед објашњава дрхтање које га је обузело док се пред потером скривао у ђубрету, такође је само маска, први од неколико „велова“ које мора да раздере пробијајући се до истине. „Не! рече себи (..)Није га био спопао страх од смрти, него 
ИСПЕВАТИ ПЕСМУ, ОСВОЈИТИ СЛОБОДУ, (РАЗ)ОТКРИТИ СЕБЕ ...

страх да неће извршити задатак ако га убију. Не извршити га, била би тек смрт. Једина које се стварно бојао.“(1982:490) Признање узалудности уложених напора, за Мићу би представљало најтежи пораз, могућност која истински ужасава. Вековић ће у једном тренутку, док лежи полусвестан у затворској амбуланти, на своју ненаписану песму слободе помислити као на „храну за црве“:„Сваки песник умире с ненаписаном песмом, бољом од свих које је написао. Те песме су антологије које црви варе у својим црвљивим цревима.“(1982:603) Слично ће се Жика Рановић изразити говорећи о сину и његовим саборцима, тачније, њиховој жртви и јуришању да се међу првима докажу на бранику отаџбине. Код Миће је још експлицитније дочарано скончање наде и борбених идеала у сандуку за ђубре: „Као мехури сапунице расплинуле су се наде и маште. Нови човек! Којешта! Ето где свршава чистота његовог лика! У сандуку за ђубре свршава!“(1982:491) Тренуци очајања, дакле, у први мах претварају идеал у пропадљиву стирвину, нестајање и пораз. Али, очајање и страх због осујећености истовремено имају друго лице, а то је гнев који означава почетак борбе и промене.

Код обојице је кључан и проблем уклањања „преграда“, постизања „моралне једнакости“ са другима, иако постављен на различите начине. Потпуна прозирност и искреност човека услов су достизања савршеног света будућности. Уклањање преграда у души створиће срећан (лични) свет. Човек постаје ,јасан до краја“, не нов - већ пронађен. Када му Ана затражи да јој каже ко је заправо, Мића одговара: „Увек сам био какав је требало бити у одређеном тренутку да би се одређена акција извршила.“ (1982:561) Своју новонасталу „обичност“ схвата као изједначеност са светом и неопходно помирење - али и „Племенито“ унижење (ово је и те како приметно кроз иронију и снисходљиви призвук): „Он није више онај стари Мића с претензијама на изузетност, он је обичан, анониман борац. Њему је доступан сада и цвокот и све. Он нема права више да себи забрани ишта људско. Он је морално изједначен са сваким обичним борцем. “(1982:502, подвукла И.Ђ.) У појединим тренуцима, Мића готово бахато и имплицитно унижавајуће представља себи „нови“ идентитет: „Он није крив ни за чију смрт, ни за чије хапшење. Он је слободан, јер је обичан. Он ништа више не треба да сачува по сваку цену. Ни живот.“ Све је gозвољено бориу за буяућносй. Може се бийи и макро револуичје, ако јој 
йо служи.(1982:502) И код Ане ће непрекидно преиспитивати себе, готово рефренски убеђујући: „Стари Мића је остао у сандуку за ђубре са својим уседеличким илузијама. Он је сад други Мића, човечнији. Ако је и даље борац који је био, он је то на један еластичнији, лењинскији начин.“(1982:507) Истовремено, осећаће стид и нешто налик смртној пресуди при сваком њеном захтеву да јој изјави љубав.

Овај је компромис можда дошао брзо, али, свакако не и лако. У души, остаје растрзан и противречан, што Вековића заобилази, јер пронашавши решење за песму, добија одговор за даље. Дотле се Мићин лик, као прави вилин коњии исцрпљује двоструком борбом и не би могао опстати, ни знао постојати, у мирнодопском раздобљу. У оба случаја, мисли, идеје и духовна лутања воде од позе (психички потпуно разрађене) до апсолутне искрености, огољавања, признања. А управо је признање корак према суштини, одлука о вишеструком јединству: идеологије и живота, воље (контроле) и спонтаности контакта, индивидуалног са колективним.

\section{4. Песма измирења, песма страдања}

Вековић први смешта читав неисрцпно симболичан смисао (за којим трагају јунаци романа) у песму. Оно што је за Мићу слобода, уметник проналази у некој будућој, још неиспеваној - али наслућеној песми, за коју се читавог живота припрема и која је исходиште сваког предузетог напора, чије настајање (коначно уобличење) оправдава постојање њеног аутора.

Није тешко уочити како су Вековићева иеесма и Мићина слобоgа једно те исто, да им претходе дуготрајне „свесне припреме“. У тај се разноимени појам улива још много других (истина, једнакост, правда, срећа, братство, љубав, реч, садашњост), а сви скупа означавају најузвишенији идеал, врхунско вредносно начело које обухвата целину постојања. У питању су, дакле, идеални појмови, „нешто опште и непроменљиво, попут Платонових идеја, што треба да доведе до правог разумевања и споразумевања у комуникацији“ (Стојановић, 1977:75). И Вековић и Мића сањају исту иесму, до које се стиже и чије је освајање крајње неизвесно, али, сам покушај да откријемо њену природу вредан је сваког напора. Није случајно одабрана симболика песме, која је једним делом израз стваралачке снаге човечанства - побуне ума против слепе задатости, испољавање и непристајање на 
ИСПЕВАТИ ПЕСМУ, ОСВОЈИТИ СЛОБОДУ, (РАЗ)ОТКРИТИ СЕБЕ ...

пасивну трпељивост, а с друге стране хармонија, сагласје међу елементима универзума. Револуција као песма и живот као песма подразумевају струјање, ток, помиреност човечанства међу собом, а јуриш на препреке и неправде. Реч добија „егзистенцијално значење“ (Константиновић, 1969:210), изашавши из језичке сфере свакодневног говора. Песма постаје израз оног најдубљег и најживотворнијег у човеку.

У судбоносном тренутку, ни Мића ни Вековић, не жале за животом самим, већ - први за испуњењем задатка спасавања заробљеног песника, а други за ненаписаном песмом. Мићин успех у подухвату вратио би му поверење другова, дакле, донео не само афирмацију себе као активног борца, већ и повратак под окриље колектива, сада са додатним вредносним доказом. На ширем плану, Мића је неко ко помаже настанак песме, инспирисањем и ослобађањем њеног творца. У тој тачки се њихови путеви спајају. Вековић у тренуцима очајања пати што „неће написати песму свога живота.“ Упоредимо ли га са Мићом, поред упадљиве сличности дугогодишњих „свесних припрема“, уочићемо још једну паралелу по супротности (обрнутом редоследу). Наиме, пита се зашто је протраћио толико времена на жене каg uх није желео, уместо да сеgи и йише, док је Мића своје време у потпуности испунио лишавањем и одрицањем.

Мићин идеал ће се, међутим, тек прочишћен кроз откривање и буђење људскости у љубави са Аном, показати као јаснији, приземнији, али и човечнији. Вековићева песма може настати у пуној снази тек под утицајем заробљеничког искуства и Сашиног примера (јер, она је вероватно прва жена која га не фасцинира примарно еротски, нити буди жељу за поседовањем, већ је дирнут њеном лепотом борца и мајке) - као репрезента gyше нароgа коју открива и упија сапатништвом. Међутим, завршетак романа показује и то како је идеал истовремено незадржив, на корак од остваривости - јер, Мића гине, а Вековићева судбина остаје неизвесна. Питање хоће ли песник на крају изаћи на слободну територију и након тога саставити песму, остаје отворено. Постоји још једна претпоставка, односно, могућност тумачења - Мића својим страдањем „уграђује“ себе у борбу, учинивши сопствени живот иесмом: умире као вилин коњиц, вечито млад, у жару борбе. А уколико се присетимо да је Ана Мићу први пут угледала „у огледалу“, као једно магновење, из Вековићеве поетичне дефиниције 
Исидора Д. Ђоловић

приметићемо како је истакнути појам повезан са борбом и песмом, које се одвајају када више није неопходно да подстичу једна другу. Утолико ће Мићи бити лакше да напусти Ану и продужи ка својој примарној мисији, ничим задржан.

Слобода је истина и песма, налази се у срцу дела, Мићине строге аутодисциплине и Вековићеве потраге. Слобода остаје онда када се биће прочисти од свега (идеала, нагона, титула), она је избор и право да се делује, воли, буде истинит. Ана не тежи правој слободи, али је може посредовати - она жели „ропство“ (чулима и осећањима), повезаност у ропству, док Мића и Вековић, преузимајући вредности оног другога, остварују кораке ка жељеној слободи. Вековић мора научити да пречисти нагоне до општељудске (заборављене) емпатије, а женски посредник на том путу је Саша. Мића мора да пречисти аутодисциплину и задатости до нагона, у чему посредује Ана. Међутим, она није носилац најчистије и најснажније емоције према Мићи: то је Жика Рановић, његов отац. Родитељска љубав коју Жика гаји застрашујућа је, огромна, болна и тешка.

Мића се посебно очајнички борио да одржи превласт „свести и воље“, мада у њему струји понорница нагонског, људског. Његов немир невидљив је за Вековића, кога младићева привидна, провокативна постојаност доводи до колебања. Заједничко им је што (поновно) откриће слободе (Вековић) и људскости (Мића) обојицу „враћа детињству“, осуђујући дотадашњу ,јалову усамљеност“. Они се неће суштински променити, јер циљ и курс кретања остају исти као и раније, али, нов је начин сагледавања ствари. Како Мића закључује, заправо није потребно измислити и (изнова створити) другачију, већ поново иронаћи истинску, прочишћену љубав, поезију, солидарност, веру у идеал.

Због тога потрага за песмом подразумева измиреност, али и жртву, као коначни, врхунски израз стапања са целином постојања. Тада се страдање више не сматра порицањем себе, већ пружањем живота борби - не обезличење ратника, већ његово уједињење, изједначавање са борбом. На тај начин, стиари Мића, боіайији за смрй иза себе (1982:525), постаје оно што је желео да буде: несебичан, лак и неспутан, непостојан (кратког века) - а вечан, напокон истинит - макар и у својој противречности. Јутро пред акцију доноси неку врсту спокоја у устрепталости. Чак и слика Мићине погибије садржи грч, 
ИСПЕВАТИ ПЕСМУ, ОСВОЈИТИ СЛОБОДУ, (РАЗ)ОТКРИТИ СЕБЕ ...

суспрезање, „неприродност“ положаја (никад допуштеног одмора, ни потпуног опуштања), а пад у јуришу одражава континуитет напора дотадашњег живота. Искуство откривања суштине водило је јунака, баш као и његов „одраз“, полазећи од ослушкивања гласова (савести и других) и огледања (себе у другоме), преко сазнања кроз бол и страдање, до примењене истине (стварања йесме) у, сада оплемењеној, акцији. Никада не порекавши, ни заборављајући „сталну радост борбе“, борац за слободу постаје - њена песма.

\title{
ЛИТЕРАТУРА
}

Давичо, Оскар (1982), Песма (Срӣска књижевносӣ: Роман, књига 33), Београд: Нолит.

Ингарден, Роман (1971), О сазнавању књижевної умейничкоі̄ gела,

Београд: Српска књижевна задруга.

Константиновић, Зоран (1969), Феноменолошки ӣрисииуй књижевном gелу, Београд: Просвета.

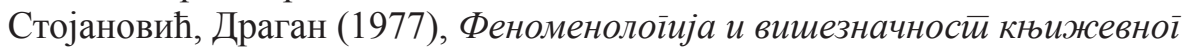
gела (Ині̄арgенова йеорија ойализаџије), Београд: „Вук Караџић“.

\section{Isidora D. Đolović}

\author{
CREATING A POEM, WINNING THE FREEDOM, \\ UNCOVERING THE SELF: PHENOMENOLOGICAL ANALYSIS \\ OF OSCAR DAVIČO'S NOVEL THE POEM
}

\begin{abstract}
Summary
The novel discussed here follows several parallel streams of consciousness, internal voices which represent dramatic mental struggles of its protagonists. All events are refracted through the prism of suspicion, division and "earthquake" inside their minds and souls. At first, they represent two drastic principles that must meet halfway, through rediscovering the meaning and necessity of mutual compromise and comprehending.
\end{abstract}

Key words: феноменологија, подсвесно, рефлектовање, телесност, унутрашњи монолог, паралелизам 